\title{
Performance and Characteristics of Swedish Mutual Funds
}

\author{
Magnus Dahlquist Stefan Engström Paul Söderlind* \\ May 10, 2000
}

\begin{abstract}
This paper studies the relation between fund performance and fund attributes in the Swedish market. Performance is measured as the alpha in a linear regression of fund returns on several benchmark assets, allowing for time-varying betas. The estimated performance is then used in a cross-sectional analysis of the relation between performance and fund attributes such as past performance, flows, size, turnover, and proxies for expenses and trading activity. The results show, among other things, that good performance is to be found among small equity funds, low-fee funds, funds whose trading activity is high, and in some cases, funds with good past performance.
\end{abstract}

Keywords: Flows, persistence, portfolio evaluation, survivorship bias, style analysis.

JEL Classifications: G11, G12, G23.

*Stockholm School of Economics, and CEPR (Dahlquist), Stockholm School of Economics (Engström), and Stockholm School of Economics, and CEPR (Söderlind). We have benefited from the comments and suggestions of Stephen Brown (the Editor), Martin Edström, Hans Fahlin, and an anonymous referee. We appreciate the research assistance we have received from Ingela Redelius and Pernilla Viotti. Correspondence to: Magnus Dahlquist, Department of Finance, Stockholm School of Economics, Box 6501, SE-113 83 Stockholm, Sweden, Phone: +468736 91 56, Fax: +468312327, E-mail: magnus.dahlquist@hhs.se. 


\section{Introduction}

Investors have an obvious interest in evaluating their portfolios. As a result, a large number of fund performance evaluations have been carried out. Recently, several studies have gone one step further by considering the relation between performance and fund-specific attributes to enable a better understanding of performance. This is also a first step toward forecasting, and perhaps even toward explaining, performance. Most studies have been of U.S. fund data, and they have often found that flows, current performance and fees may predict future performance (see, e.g. Ippolito (1989), Elton, Gruber, Das, and Hlavka (1993), Gruber (1996), Carhart (1997), Sirri and Tufano (1998), and Zheng (1999)).

This paper studies the relation between fund performance and fund attributes in another market, namely the Swedish market. There are two main motivations. First, by looking at a different market, but one with a similar institutional setting (discussed in some detail in the paper), we can provide the existing literature with out-of-sample evidence. Second, the Swedish data are comprehensive, allowing us to analyze interesting hypotheses and to avoid a number of pitfalls. For instance, we have a rich dataset of attributes including fund size, various fees and measures of trading activity as well as the more standard attributes such as lagged performance and flows. We also have data on virtually all the funds that existed at any time during the sample period and therefore no survivorship bias should exist.

We first estimate the performance of Swedish funds for the period 1993 to 1997 as a Jensen's alpha in a linear regression of the fund return on a constant and several benchmark returns. The slope coefficients (betas) are allowed to vary with information variables as in Ferson and Schadt (1996). This can be viewed as measuring performance relative dynamic strategies which are linear in the information variables, and therefore easily implemented by investors. This conditional evaluation of the funds suggests that the performance of regular equity funds has been neutral. The equity funds in the

public savings program (with certain tax advantages) appear to have had a negative relative performance (before tax). Moreover, the bond and money market funds have significantly underperformed.

The estimated performance is then used in a cross-sectional study of the relation between performance and fund attributes such as past performance, inflows and outflows, size, turnover and various proxies for expenses and trading activity. We make a strong effort to establish robust results by using a range of different statistical methods and 
by comparing the performance of different trading strategies based on the attributes. The latter also provides an economically meaningful measure of the magnitude of the relation between performance and attributes.

A number of results emerge from the cross-sectional analysis. First, large equity funds tend to perform less well than small equity funds, while the opposite holds for bond funds. One potential explanation might be that large equity funds are actually very large in relation to the Swedish equity market, whereas the bond funds are fairly small players on the bond market. Even if some returns to scale are to be found in fund management, as suggested by the results for the bond funds, the large equity funds may simply be too large for aggressive trading. Second, performance is negatively related to fees, that is, high-fee funds tend to underperform relative to low-fee funds. In some cases, however, high-fee funds perform better than low-fee funds before fees are deducted. This suggests that high fees - or expensive management - may be able to generate good performance, but not enough to cover the fees. (This is in line with the next finding.) Third, actively managed equity funds perform better than more passively managed funds. Fourth, we find evidence of persistence in performance for money market funds, but not for the other fund categories.

The rest of the paper is organized as follows: Section II provides a brief description of the data and Section III presents the performance results. In Section IV, performance is related (in a panel/cross-sectional analysis) to fund attributes and trading strategies based on the set of attributes. Finally, Section V offers our conclusions.

\section{Data}

\section{A. Swedish Mutual Funds}

The public interest in the Swedish mutual fund industry has grown rapidly. For instance, in 1995 households' bank deposits amounted to some SEK 386 billion, whereas mutual fund holdings were worth SEK 242 billion. (During the sample period, one USD was worth about SEK 8.) Two years later, bank deposits had risen only slightly to SEK 392 billion, but holdings in mutual funds had almost doubled by 1997 to SEK 456 billion. In 1998, savings in funds constituted as much as $20 \%$ of the financial savings of households, and more than $50 \%$ of the population saved in mutual funds. The increased interest in saving in mutual funds can perhaps be explained by high savings ratios in general, and the deregulation of the credit market and the move toward 
private pension plans in particular.

This study looks at Swedish mutual funds from the end of 1992 to the end of 1997. The choice of period is simple: only a few funds existed before 1991. Swedish mutual funds are open-end funds and investment policy regulations have been harmonized within the European Union through UCITS (Undertakings for Collective Investments in Transferable Securities), which is similar to the U.S. Investment Company Act of 1940. The funds are broadly categorized by Finansinspektionen, the Swedish Financial Supervising Authority, according to primary investment objectives. Equity funds are divided into regular equity funds (Equity I) and Allemansfonder (Equity II). The latter are part of a public savings program and offer tax benefits. ${ }^{1,2}$ The investment style of the funds is either general market funds or small stocks. Bond funds invest in mortgage and government bonds, while mixed funds invest in both equity and debt instruments.

We divide the dataset into Finansinspektionen's classifications, with the exception of money market funds which we place in a separate category. We exclude funds that invest in foreign markets since they have different risk exposures that would require additional benchmarks to span the investment opportunity set. We focus on Swedishbased funds as it is difficult to take into account the different tax regulations that apply to the funds and/or their holders. In total we consider 80 Equity I funds, 46 Equity II funds, 42 Bond funds, and 42 Money Market funds. Although we only consider Swedish-based funds investing in Sweden (about $20 \%$ of all funds), we cover a large part of the mutual fund industry. For instance, we cover about $65 \%$ of the total net asset values of equity funds.

We have obtained net asset values (NAVs) for all funds from the TRUST database of Findata. The NAVs account for capital gains, dividends (reinvested) and administrative fees (subtracted), and were used to calculate weekly returns. We have been able to (manually) collect various fund characteristics/attributes from quarterly reports obtained via Nya Finans and Sparöversikt (the publications of Finansinspektionen, and

\footnotetext{
${ }^{1}$ During 1993, 1995, and 1996 the tax rate on capital gains for Equity II funds was $20 \%$ compared with $30 \%$ on other funds. In 1994 and 1997 the tax rate on these funds was the same as on other funds, that is, $12.5 \%$ and $30 \%$ respectively.

${ }^{2}$ Equity I and II funds also differ with regard to portfolio restrictions. Equity I funds have not been allowed to hold a single stock worth more than $10 \%$ of their total assets. Moreover, they have only been allowed to hold stocks with more than $5 \%$ of total assets to a maximum of $40 \%$ of total assets. The restrictions for the Equity II funds meant that they were not allowed to invest more than $10 \%$ of total assets in a single stock. These restrictions have potentially been binding for two firms (Astra and Ericsson). We find that the difference between the returns on a general market index, with or without these restrictions, to be small, and we therefore do not elaborate further on this.
} 
Swedish Fund Statistics respectively), and from annual reports of the funds. The attributes are size, net flows, administrative fees, exit and loading fees, turnover and commission, and they are all computed on an annual basis.

The size of a fund is measured as the total net asset value of each fund's portfolio. The net flows (or new money) during a quarter are approximated from the returns and the total net asset values under the assumption that all new money is invested at the beginning of the quarter. The flow of new money into fund $i$ over the period from $\tau-1$ to $t, F_{i \tau}$, is then calculated according to

$$
F_{i \tau}=T N A_{i \tau}-T N A_{i \tau-1} \times N A V_{i \tau} / N A V_{i \tau-1}
$$

where $N A V_{i t}$ and $T N A_{i t}$ denotes the net asset value and total net asset value of fund $i$ at time $t$. Hence, $F_{i \tau}$ measures the change in a fund's assets beyond reinvested capital gains and dividends. Administrative fees are expressed as a percentage of assets invested. Exit and loading fees are expressed as a percentage of assets invested; turnover is expressed as the minimum of purchases and sales over average assets (in $\%$ ) during a year. Commission is the fee the equity funds pay for their trading, and are expressed here as the percentage of average assets. Notice that all returns used in the evaluation are net of administrative fees and commissions, but before exit/loading fees and taxes.

Table 1 presents some descriptive statistics on the four categories of funds. The aggregated total net asset values in December 1997 are about the same for Equity I and II funds, even if the average Equity I fund is only a third of the size of the average Equity II fund. The overall net flow into our sample of funds has in the aggregate [Hint: Table 1 about been positive. The cost of administrative fees is about $1.5 \%$ in both equity categories, which is more than twice as high as that in the bond fund category (about 0.7\%). The differences in turnover across the categories are interesting. Bond funds have the highest turnover - about $180 \%$ of their average asset values are purchased or sold over one year. The corresponding figures for Equity I and Equity II funds are $75 \%$ and $47 \%$ respectively, indicating that Equity II funds are less active than Equity I funds. Consequently, the commission costs for Equity I funds are consistently higher than for Equity II funds.

The fund characteristics can be compared to those of U.S. funds. In terms of expenses, investment fees, portfolio turnover and trading costs, they are about the same as for U.S. funds (see Ippolito (1992), and Pozen (1998)). Passive management 
fees in the U.S. are about $50 \%$ lower than traditional active management fees. We believe that Equity II funds are more like passive pension funds, but in contrast to passive funds in the U.S., their fees are similar to those of active funds. Overall, we find our sample of funds to be rather similar to U.S. funds.

\section{B. Benchmarks and Conditional Information}

In the performance evaluation, our aim is to compare the returns on a fund with the returns on certain benchmarks. For tractability and to facilitate interpretations, we use returns on broad asset classes to represent the investment opportunity set. We allow, however, for dynamic strategies according to some predetermined information variables.

More specifically, to capture the developments in the stock market, we use the returns on two equity indices. The first index is the general stock market as measured by Findatas Avkastningsindex. This index is a value-weighted index (which accommodates buy-and-hold strategies) with reinvested dividends. It includes stocks with the most stringent listing requirements on the Stockholm Stock Exchange (SSE). The second index is a small firm index which we have constructed. We have used the same population as the (Swedish) Carnegie Small Cap Index, and a similar weighting method. The main difference is that the index we have constructed includes dividends.

To capture the development in the bond market, we use two bond indices (consisting of both government and mortgage bonds) provided by Findata. One is a total bond index with an average duration of four years, and the other is a money market index consisting of (approximately) 180-day T-bills. The returns on benchmarks and funds are measured in excess of a 7 -day interbank rate (STIBOR) that is used as a proxy for a riskfree investment.

Predetermined conditional information variables are used to capture potential timevariation in risk and expected returns. Following Dahlquist and Söderlind (1999), we use as instruments the lagged market return and the level of the yield curve (stochastically de-trended to dampen the otherwise extreme autocorrelation).

\section{Evaluating Fund Performance}

In this section we evaluate the performance of Swedish-based mutual funds investing in Swedish assets during the period 1993 to 1997. As our sample contains virtually 
all the funds that existed during this period, the results should not be affected by a survivorship bias. Later in this section, we quantify the size of the survivorship bias that would have occurred if we had only used funds that were still alive at the end of the period.

\section{A. Results of the Performance Evaluation}

In the evaluation, we want to decompose a manager's return into the part that is systematic (and can be replicated by benchmarks or broad market indices), and the non-systematic part which can be referred to as the risk-adjusted performance. Naturally, we are interested in evaluating the part of the return which cannot be attributed to general risk-taking. Following Ferson and Schadt (1996), we consider two benchmark models - one unconditional and one conditional.

In the unconditional model constant betas are used, whereas the conditional model allows for time-variation in betas through predetermined information variables. In both cases we obtain an alpha (the deviation from the benchmark model). A positive (negative) alpha is interpreted as overperformance (underperformance), and it measures the performance in comparison with simple trading rules that individual investors could implement. We use broad benchmarks to capture the investment styles of the funds. For equity funds we use the general market portfolio and a small firm index; for bond funds we use the returns on the two bond indices - each capturing different segments of the maturity structure. As conditional information we use the lagged market return and the level of the yield curve.

The results of the evaluation are summarized in Table 2. We estimate the coefficients with least squares, but the standard errors are designed to allow for heteroskedasticity and serial correlation (as in White (1980) and Newey and West (1987)). The simulation evidence in Dahlquist and Söderlind (1999) suggests that the small sample distribution of the t-statistics for neutral performance are well approximated by the asymptotic distribution. To offer some insights into how the mutual funds - as an industry - have performed, we also include value-weighted alpha measures in the table. We choose to focus the discussion on the performance results obtained from the conditional model. This can be justified by considering the Wald statistics in the table - the hypothesis of no time-variation in the betas is rejected for $53 \%$ to $77 \%$ funds in the four fund categories.

Equity I funds have, on average, an alpha of $0.5 \%$ per year. In other words, on 
average, the funds have outperformed the market. The overperforming funds deviate more than the underperforming funds, thus the median is only $0.1 \%$ per year. Furthermore, only $10 \%$ of Equity I funds show statistically significant positive alphas. Note that administrative fees directly affect the return on the funds. For Equity I, the fees have averaged $1.4 \%$ per year, and therefore, an alpha of about $0.5 \%$ against costless benchmarks is quite substantial.

Equity II funds have performed less well, with an average conditional alpha of $-1 \%$ per year. The distribution of Equity II funds is also skewed (the median is about $-1.7 \%$ per year). The administrative fees for these funds are about $1.5 \%$, and if they were excluded the performance would be more neutral. One explanation for the weaker performance of Equity II funds is that the competitive pressure is low because of the tax advantages they offer.

The Bond and Money Market funds show inferior performance. The average (and median) is about $-0.5 \%$ per year for Bond funds, and about $-0.9 \%$ per year for Money Market funds. Interestingly, about $90 \%$ of the Money Market funds have significantly negative alphas, whereas only $24 \%$ of the Bond funds have significantly negative alphas. The underperformance for Money Market funds is $0.2 \%$ higher than their average administrative fee.

We analyze the robustness of the performance results by changing the set of benchmark assets and adding non-linear terms as proxies for market timing as in Henriksson and Merton (1981) and Treynor and Mazuy (1966). (These results are not reported in a table.) The overall findings show that the previous results are not sensitive to these changes.

\section{B. Survivorship Biases}

The results presented above should not suffer from survivorship biases since we make use of virtually all the funds that existed between 1993 and 1997. By the same virtue, our dataset allows us to investigate what kind of performance a sample of only surviving funds would give.

A number of studies have noted that estimates of performance are biased upwards because of survivorship. An upward bias is a likely outcome if it is the poor performers that are liquidated or merged into other funds.

We first considered the entry and exit of funds on a year-by-year basis together with attrition and mortality rates of the funds (not reported in a table). The attrition rate is 
the percentage of funds that left the sample. The attrition rates for the Equity I, Bond, and Money Market categories range from $2 \%$ to 21\%. The average rate for Equity II funds is much lower, about $2 \%$ to $3 \%$ (1997 is an exception). The attrition rates can be compared with those found in U.S. mutual fund databases, where Grinblatt and Titman (1989), and Brown, Goetzmann, Ibbotson, and Ross (1992) find attrition rates that range from $2.6 \%$ to $8.5 \%$, with an average of about $4.5 \%$. That is, the average attrition rates in our database are about the same, although they seem to be more volatile over the years. The majority of the funds that exit the sample are merged into other funds (80\%), but in some cases the funds change investment objective (go global), and cease to exist. When the funds merge into another fund family, the return history of the old fund is discarded.

Table 3 presents estimates of the survivorship biases. We construct a direct measure of the bias by comparing two different portfolios. The first portfolio (labeled All) is the return on an equally-weighted portfolio of all the funds in existence each week. This portfolio has, by construction, the same survivorship experience as the overall sample. The second portfolio, however, only consists of surviving funds (labeled Surviving), that is, funds that exist at the end of the sample period. The measure of survivorship bias is the difference between the two portfolios (Surviving and All).

We find that non-surviving funds perform less well than surviving funds. The return difference, however, varies across the fund categories. For the Equity I funds, it is fairly high, about $0.6 \%$ to $0.7 \%$ per year, whereas the estimated bias for the other fund categories is lower (on average about $0.1 \%$ per year). The biases on a year-byyear basis fluctuate considerably. To infer the survivorship bias for the industry as a whole, we also consider value-weighted portfolios. We then find a somewhat smaller bias, indicating that smaller funds are typically more likely to leave the sample.

The estimated biases can be compared to findings using U.S. mutual fund data. For instance, Grinblatt and Titman (1989) find a survivorship bias of about $0.5 \%$ per year, and Brown and Goetzmann (1995) estimate the survivorship bias at $0.8 \%$ per year. However, when returns are scaled by the funds' market capitalizations, the bias is only $0.2 \%$ per year. Moreover, Malkiel (1995) reports a bias as high as $1.4 \%$ per year. Blake, Elton, and Gruber (1996) also find large biases (above 1\% per year) when raw returns are used, whereas the bias is about $0.7 \%$ on a risk-adjusted basis. Finally, in a large sample of funds, Carhart (1998) documents lower survivorship biases of about $0.2 \%$ per year. Overall, we conclude that the survivorship bias in the Swedish market is in the lower range compared with estimated biases in the U.S. market. 


\section{Fund Performance and Fund Attributes}

In this section we characterize the performance of the funds using cross-sectional attributes, namely fund size, fee structure, trading activity and net flows. This is done by measuring the performance of the funds on a year-by-year basis, and then relating this to annual data on fund attributes. We are looking for results that are qualitatively the same across different methods and subsamples, and for this reason we explore several different approaches.

Our first approach is to run panel data regressions

$$
\hat{\alpha}_{i \tau}-\overline{\hat{\alpha}}_{\tau}=\gamma_{0}+\gamma_{1}\left(x_{i \tau}-\bar{x}_{\tau}\right)+\xi_{i \tau}
$$

where $\hat{\alpha}_{i \tau}$ is the estimated alpha for fund $i$ in year $\tau$, and $x_{i \tau}$ denotes a fund attribute. We allow for fixed (year) effects by subtracting the mean of the alpha and the attribute during a year, denoted by $\overline{\hat{\alpha}}_{\tau}$ and $\bar{x}_{\tau}$ respectively. The alphas are, of course, generated variables which contain measurement errors. While this does not affect the consistency of the estimators of the regression coefficients, it introduces heteroskedasticity since the different alphas are measured with varying degrees of precision. This means that ordinary least squares (OLS) is inefficient and that the traditional estimates of the standard errors are misleading. We therefore use a weighted least squares (WLS) approach where each observation is weighted by the reciprocal of its residual standard deviation from the performance regression.

Our second approach is to measure the performance of trading strategies based on the fund attributes. This gives further evidence on the cross-sectional differences and helps us to quantify them economically. The funds are first ranked according to the attribute and then formed into equally-weighted portfolios of the funds below the 40th percentile and above the 60th percentile respectively. We then construct a fictitious zero-cost portfolio by buying the "high" portfolio financed via a short-selling of the "low" portfolio. This zero-cost portfolio is held for one year. After one year, the sorting procedure is repeated, new portfolios are created, held for the subsequent year, and so on. The main results are reported in Table 4.

We attempt to establish the robustness of the findings by comparing results from different subsamples and from different estimators. We comment on these results in the text. ${ }^{3}$ We also considered regressions where administrative fees are not debited

\footnotetext{
${ }^{3}$ First, we reestimate the WLS regressions on every possible subsample of size $N-2$ drawn from the entire sample of $N$ observations and study the distribution. Second, we reestimate all regressions
} 
against the funds' NAVs prior to calculating returns. The results were very similar.

[Hint:

Table 4

about

here.]

In this subsection, we study the static relation between fund size and performance. In later subsections, we will take a closer look at how performance is related to the flow of new money into the fund.

Our results show that size has little effect on Equity I funds; some methods suggest small positive effects while other methods suggest small negative effects. However, size has a strong and robust negative relation to the performance of Equity II funds. The regression, where alpha is regressed on a constant and size, has a significant slope coefficient of -0.88 . The trading strategy of buying large funds and selling small funds generates a significant underperformance of $2.33 \%$ per year. This appears to be a robust result: the coefficients from every possible subsample, with two observations excluded, are all negative; other estimation methods (OLS, LAD, and LTS) also give negative coefficients; the rank correlation is negative; and size has a negative coefficient in a multiple regression.

There are some indications that size has a weak positive relation to the performance of Bond and Money Market funds. For the Money Market funds, all regression coefficients, and also the rank correlation, are slightly but significantly positive. However, the trading strategy of buying large funds and selling small funds generates neutral performance. For the Bond funds, only the trading strategy signals a significantly positive relation, and some of the regression coefficients are even negative, although not significantly so. Overall, we consider this to be weak evidence of a positive relation to size.

There are also some indications that size is important in a comparison across fund categories - at least for Equity I and II. Equity II funds are typically much larger than Equity I funds, trade less, and perform less well.

These findings could perhaps be explained by the fact that Equity I funds, Bond funds, and Money Market funds are quite small compared with their respective markets, whereas Equity II funds are relatively large compared with the equity market. The using robust estimators such as the method of least absolute deviations (LAD) and the method of least trimmed squares (LTS) which put less weight on outliers. Third, we estimate multiple panel data regressions, that is, to let $x_{i \tau}$ in $(2)$ be a vector of all available fund attributes. To use all available data, we apply the two-step approach in Griliches (1986). Fourth, we estimate the correlations of the relative ranks (for each year) of the fund's alpha and attribute. 
largest Equity II funds may simply be too large to adopt aggressive trading strategies.

\section{B. Fee Structure}

The direct effect of the administrative fee is to weaken performance one for one (the fee is in percent per annum) since the fee is subtracted from the fund wealth to generate the net asset values. Indeed, we find that the administrative fee has a robust negative relation to the performance of Equity I funds and Money Market funds. For Equity I funds the regression coefficient is actually less than minus one $(-1.40)$. For Money Market funds, the regression coefficient is -0.24 , which suggests that efficient management offset three quarters of the direct effect of the fee. There is also some evidence of a weak negative relation for Equity II funds, but no significant results for Bond funds.

The exit and loading fees are not directly subtracted from the fund wealth, but they decrease the return to the investor. To compensate investors for a one-year round-trip, the performance would need to increase one for one by the sum of these fees, which is the measure we use. However, our results show the hypothesis of a coefficient of one can easily be rejected for all fund categories. Rather, some evidence suggests a negative relation to performance for the Bond and Money Markets funds.

The evidence from U.S. data is somewhat mixed. On the one hand, Ippolito (1989) finds that high-fee U.S. funds also perform relatively well - even well enough to offset the higher fees. However, in their reinterpretation of this evidence, Elton, Gruber, Das, and Hlavka (1993) and Carhart (1997) argue that high-fee funds do not perform as well as low-fee funds.

\section{Trading Activity}

We use two different measures of trading activity. The first measure is turnover, which we calculate as the minimum of purchases and sales divided by the fund size. This definition allows us to capture the active management of the portfolios, and not just whether a fund is growing or shrinking. The second measure is commission fees paid by the fund (trading costs), divided by the fund size. Like the administrative fees, the commission fees paid by the fund have a direct one for one (negative) effect on performance. However, the active management of the portfolio might be able to offset this effect.

We limit the analysis to equity funds, since it proved to be very difficult to obtain useful data for the Bond and Money Market funds. For Equity I funds, a positive and 
reasonably robust relation exists between trading activity and performance. For Equity II, we find no relation. Again, it is also worth noting the differences across the fund categories. Equity II funds are typically much larger and trade less than Equity I funds - and they also perform less well.

\section{Net Flows into Funds}

In this subsection, we study if money flows into funds which will overperform in the near future. Gruber (1996) and Zheng (1999) provide evidence of such "smart money" in U.S. data.

We find very little evidence of a relation between lagged flows and performance. The results reported are from an analysis of net flows, but they are very similar to those obtained with growth in flows (net flows divided by total net assets). The only significant result is for the trading strategy for Equity II funds, where buying funds with high lagged flows and selling funds with low lagged flows generates an overperformance of about $2 \%$ per year. However, this does not appear to be a very robust result since the other approaches give very mixed results.

\section{E. Persistence in Performance}

A large literature addresses persistence in U.S. mutual fund performance. The results seem to suggest some persistence, mainly for the worst-performing funds. ${ }^{4}$ We estimate persistence in performance by treating the alpha for the previous year as an attribute and then proceed as we did earlier.

We measure performance in excess of the annual industry average, which means that we are effectively looking for persistence in relative performance. The results in Table 4 suggest that there is no significant persistence for Equity I funds, Equity II funds, or Bond funds. This is verified by the results from an IV estimator (to account for the measurement errors in the regressor; rank index used as instrument) and the other estimators.

However, a robust persistence is found in the performance of Money Market funds. The first order autocorrelation is 0.38 . Once again this result is verified by the IV

\footnotetext{
${ }^{4}$ Evidence of persistence for negative performers is reported by Hendricks, Patel, and Zeckhauser (1993), Carhart (1997), and Christopherson, Ferson, and Glassman (1998). Positive persistence in performance is documented in, for instance, Goetzmann and Ibbotson (1994), Grinblatt and Titman (1992), Hendricks, Patel, and Zeckhauser (1993), and Malkiel (1995). The repeated winners results can, however, be attributed to survivorship biases (as discussed in Brown and Goetzmann (1995), and Brown, Goetzmann, Ibbotson, and Ross (1992)).
} 
method and the other methods. The persistence is concentrated to winners: the probability of remaining a winner is 0.35 while the probability of remaining a loser is 0.25 . The persistence results for Money Market funds are even stronger when administrative fees are not debited against funds' NAVs.

It is worth noting that Swedish stocks - contrary to most developed marketshave not shown significant evidence of so called momentum (see Rouwenhorst (1998)). Hence, the documented exposure to momentum strategies of U.S. mutual funds reported in Grinblatt, Titman, and Wermers (1995) and Daniel, Grinblatt, Titman, and Wermers (1997) does not seem to be present in Sweden.

\section{F. Domestic Funds versus Offshore Funds}

Finally, we consider 9 equity funds (corresponding to Equity I), 14 bond funds, and 6 money market funds which are based in Luxembourg and invest in Swedish assets only. The difference between Sweden-based and foreign-based funds lies in the tax rules that apply to them. It is, however, difficult to draw firm quantitative conclusions regarding the tax benefits of foreign-based funds.

The Luxembourg-based equity funds perform less well than Sweden-based funds; their median attributes are similar, but they are on average much smaller and charge higher loading and/or exit fees. The Luxembourg-based equity funds also show a higher exposure to smaller stocks.

The Luxembourg-based bond and money market funds perform much the same as the Sweden-based funds. However, they are 3 to 6 times larger, and they charge much higher loading and/or exit fees. When we include them in the cross-sectional analysis above, we find no qualitative differences compared with the results obtained with only Sweden-based funds. Hence, the performance and characteristics of the Luxembourgbased funds are on the whole similar, but they typically charge higher fees.

\section{Conclusion}

In this paper we provide extensive evidence on fund performance and characteristics of Swedish mutual funds, and document an economically significant survivorship bias for regular equity funds. Taking this bias into account, the performance evaluation shows mixed results for different categories of funds. A conditional evaluation suggests that the performance of regular equity funds has been neutral or somewhat superior. 
Equity funds in the public savings program offering certain tax advantages, and bond and money market funds performed less well, and we document significantly negative alphas for these fund categories. The measured performance results are very robust.

We also relate the measured performance to fund-specific characteristics in the cross-section of funds, and evaluate trading strategies that are based on these crosssectional differences. First, we find that larger equity funds tend to perform less well than smaller equity funds. Larger bond funds, however, seem to have performed better than smaller bond funds. Second, our results indicate that the measured performance is negatively related to fees, that is, high-fee funds seem not to perform as well as lowfee funds. Third, we find some evidence suggesting that actively managed equity funds perform better than more passively managed funds. Fourth, we find a positive relation between lagged performance and current flows. Finally, we find evidence of persistence in performance for money market funds, but not for the other fund categories. 


\section{References}

Blake, C. R.; E. J. Elton; and M. J. Gruber. "Survivorship Bias and Mutual Fund Performance." Review of Financial Studies, 9 (1996), 1097-1120.

Brown, S. J., and W. N. Goetzmann. "Attrition and Mutual Fund Performance," Journal of Finance, 50 (1995), 679-698.

Brown, S. J.; W. N. Goetzmann; R. G. Ibbotson, and S. A. Ross. "Survivorship Bias in Performance Studies." Review of Financial Studies, 5 (1992), 553-580.

Carhart, M. M. "On the Persistence of Mutual Fund Performance." Journal of Finance, 52 (1997), 57-82.

Carhart, M. M. "Mutual Fund Survivorship." Working Paper, Goldman Sachs Asset Management (1998).

Christopherson, J. A.; W. E. Ferson; and D. A. Glassman. "Conditioning Manager Alphas on Economic Information: Another Look at the Persistence of Performance." Review of Financial Studies, 11 (1998), 111-142.

Dahlquist, M., and P. Söderlind. "Evaluating Portfolio Performance with Stochastic Discount Factors." Journal of Business, 72 (1999), 347-383.

Daniel, K.; M. Grinblatt; S. Titman; and R. Wermers. "Measuring Mutual Fund Performance with Characteristic Based Benchmarks." Journal of Finance, 85 (1997), $1088-1105$.

Elton, E. J.; M. J. Gruber; S. Das; and M. Hlavka. "Efficiency with Costly Information: A Reinterpretation of Evidence from Managed Portfolios." Review of Financial Studies, 6 (1993), 1-22.

Ferson, W. E., and R. Schadt. "Measuring Fund Strategy and Performance in Changing Economic Conditions." Journal of Finance, 51 (1996), 425-461.

Goetzmann, W. N., and R. G. Ibbotson. "Do Winners Repeat? Patterns in Mutual Fund Performance." Journal of Portfolio Management, 20 (1994), 9-18.

Griliches, Z. "Economic Data Issues." In Handbooks in Econometrics, Vol. III, Z. Griliches and M. D. Intriligator, eds. North-Holland, Amsterdam (1986).

Grinblatt, M., and S. Titman. "Portfolio Performance Evaluation: Old Issues and New Insights." Review of Financial Studies, 2 (1989), 393-421.

Grinblatt, M., and S. Titman. "Performance Persistence in Mutual Funds." Journal of Finance, 47 (1992), 1977-1984.

Grinblatt, M.; S. Titman; and R. Wermers. "Momentum Investment Strategies, Portfolio Performance, and Herding: A Study of Mutual Fund Behavior." American Economic Review, 85 (1995), 1088-1105. 
Gruber, M. J. "Another Puzzle: The Growth in Actively Managed Mutual Funds." Journal of Finance, 51 (1996), 783-810.

Hendricks, D.; J. Patel; and R. Zeckhauser. "Hot Hands in Mutual Funds: Short-Run Persistence of Relative Performance, 1974-1988." Journal of Finance, 48 (1993), 93-130.

Henriksson, R. D., and R. C. Merton. "On Market Timing and Investment Performance II: Statistical Procedures for Evaluating Forecasting Skills." Journal of Business, 54 (1981), 513-534.

Ippolito, R. A. "Efficiency with Costly Information: A Study of Mutual Fund Performance." Quarterly Journal of Economics, 104 (1989), 1-24.

Ippolito, R. A. "Consumer Reaction to Measures of Poor Quality: Evidence from the Mutual Fund Industry." Journal of Law and Economics, 35 (1992), 45-70.

Malkiel, B. G. "Returns from Investing in Equity Mutual Funds 1971-1991." Journal of Finance, 50 (1995), 549-572.

Newey, W. K., and K. D. West. "A Simple Positive Semi-Definite Heteroskedasticity and Autocorrelation Consistent Covariance Matrix." Econometrica, 55 (1987), 703708 .

Pozen, R. C. The Mutual Fund Business. MIT Press, Cambridge (1998).

Rouwenhorst, K. "International Momentum Strategies." Journal of Finance, 53 (1998), $267-284$.

Sirri, E. R., and P. Tufano. "Costly Search and Mutual Fund Flows." Journal of Finance, 53 (1998), 1589-1622.

Treynor, J. L., and K. Mazuy. "Can Mutual Funds Outguess the Market?." Harvard Business Review, 44 (1966), 131-136.

White, H. L. "A Heteroskedasticity-Consistent Covariance Matrix Estimator and a Direct Test for Heteroskedasticity." Econometrica, 48 (1980), 817-838.

Zheng, L. "Is Money Smart? A Study of Mutual Fund Investors' Fund Selection Ability." Journal of Finance, 54 (1999), 901-933. 
Table 1: Individual Fund Characteristics

\begin{tabular}{|c|c|c|c|c|c|c|c|}
\hline $\begin{array}{l}\text { Fund } \\
\text { Category }\end{array}$ & $\mathbf{N}$ & TNA & Size & Flow & $\underset{\text { Fee }}{\text { Adm. }}$ & Turnover & Commission \\
\hline Equity I & 80 & 90,739 & $\begin{array}{c}568 \\
(171)\end{array}$ & $\begin{array}{l}108 \\
(22)\end{array}$ & $\begin{array}{c}1.4 \\
(1.3)\end{array}$ & $\begin{array}{l}75 \\
(55)\end{array}$ & $\begin{array}{c}0.4 \\
(0.2)\end{array}$ \\
\hline Equity II & 46 & 107,151 & $\begin{array}{c}1,862 \\
(1,224)\end{array}$ & $\begin{array}{l}-91 \\
(-20)\end{array}$ & $\begin{array}{c}1.5 \\
(1.5)\end{array}$ & $\begin{array}{c}47 \\
(40)\end{array}$ & $\begin{array}{c}0.2 \\
(0.2)\end{array}$ \\
\hline Bond & 42 & 19,338 & $\begin{array}{c}404 \\
(228)\end{array}$ & $\begin{array}{l}-8 \\
(-2)\end{array}$ & $\begin{array}{c}0.7 \\
(0.8)\end{array}$ & $\begin{array}{l}180 \\
(165)\end{array}$ & - \\
\hline Money Market & 42 & 13,481 & $\begin{array}{c}321 \\
(152)\end{array}$ & $\begin{array}{l}15 \\
(4)\end{array}$ & $\begin{array}{c}0.7 \\
(0.7)\end{array}$ & - & - \\
\hline
\end{tabular}

This table shows characteristics for the sample of funds for the period 1992 to 1997. N and TNA refer to the number of funds and the total net assets in SEK million of each fund category on December 31, 1997. The table also contains means and medians (in parentheses) across funds for various attributes: size refers to the market capitalization (in SEK million) of the fund during its sample period; flow is the average net flow (in SEK million) into the fund per year; adm. fee refers to the administrative fees as a percentage of assets invested; turnover is the minimum of purchases and sales over average assets (in \%), and commission is the fee paid by the fund at purchases and sales and is related to average assets (reported in \%). Turnover is not reported for Money Market funds. Bond and Money Market funds pay no commission. 
Table 2: Performance Measures

\begin{tabular}{|c|c|c|c|c|c|c|c|c|}
\hline \multirow[b]{2}{*}{$\begin{array}{l}\text { Fund } \\
\text { Category }\end{array}$} & \multicolumn{2}{|c|}{ Unconditional } & \multicolumn{6}{|c|}{ Conditional } \\
\hline & $\alpha$ & $\mathbf{R}^{2}$ & $\alpha$ & $\mathbf{R}^{2}$ & $\alpha^{w}$ & Wald $^{-}$ & Wald $^{+}$ & Wald \\
\hline Equity I & $\begin{array}{c}0.24 \\
(-0.27)\end{array}$ & $\begin{array}{c}0.86 \\
(0.89)\end{array}$ & $\begin{array}{c}0.52 \\
(0.08)\end{array}$ & $\begin{array}{c}0.88 \\
(0.89)\end{array}$ & 1.02 & 0.04 & 0.10 & 0.61 \\
\hline Equity II & $\begin{array}{c}-1.30 \\
(-2.17)\end{array}$ & $\begin{array}{c}0.91 \\
(0.94)\end{array}$ & $\begin{array}{c}-1.02 \\
(-1.71)\end{array}$ & $\begin{array}{c}0.92 \\
(0.94)\end{array}$ & -1.68 & 0.12 & 0.07 & 0.77 \\
\hline Bond & $\begin{array}{c}-0.95 \\
(-0.85)\end{array}$ & $\begin{array}{c}0.84 \\
(0.88)\end{array}$ & $\begin{array}{c}-0.53 \\
(-0.49)\end{array}$ & $\begin{array}{c}0.87 \\
(0.89)\end{array}$ & -0.45 & 0.24 & 0.02 & 0.54 \\
\hline Money Market & $\begin{array}{c}-0.85 \\
(-0.67)\end{array}$ & $\begin{array}{c}0.60 \\
(0.67)\end{array}$ & $\begin{array}{c}-0.94 \\
(-0.80)\end{array}$ & $\begin{array}{c}0.65 \\
(0.71)\end{array}$ & -0.80 & 0.90 & 0.00 & 0.53 \\
\hline
\end{tabular}

This table shows the results from unconditional and conditional evaluations of funds for the sample period 1993 to 1997 . In the unconditional model, betas are constant, whereas the conditional model allows for time-variation in betas via instruments (the lagged market return and a detrended yield curve level variable). Details of the performance measures are given in the text. The alpha, $\alpha$, refers to the average and median (in parenthesis) of the crosssectional alphas for each category. $\mathrm{R}^{2}$ is the average and median (in parenthesis) coefficient of determination across funds in the categories. The $\alpha^{w}$ in the conditional model refers to the weighted average of the individual alphas (where the weights are proportional to the total net asset values of each fund). The $\mathrm{Wald}^{-}$and $\mathrm{Wald}^{+}$statistics in the conditional model refer to tests of zero alphas, where the percentages of rejected null hypotheses at the $10 \%$ significance level is reported for negative alphas $\left(\right.$ Wald $\left.^{-}\right)$and positive alphas $\left(\mathrm{Wald}^{+}\right)$. The Wald statistic in the conditional model refers to a test of no time-variation in the betas, where the percentage of rejected null hypothesis at the $10 \%$ significance level is reported. 
Table 3: Estimates of Survivorship Biases

\begin{tabular}{|c|c|c|c|c|c|c|c|c|}
\hline \multirow{2}{*}{$\begin{array}{l}\text { Fund } \\
\text { Category }\end{array}$} & & 1993 & 1994 & 1995 & 1996 & 1997 & \multirow{2}{*}{$\begin{array}{l}1993 \text { to } \\
\text { Average }\end{array}$} & \multirow{2}{*}{$\begin{array}{r}1997 \\
\alpha\end{array}$} \\
\hline & & \multicolumn{5}{|c|}{ Averages of Excess Returns } & & \\
\hline \multirow[t]{3}{*}{ Equity I } & Surviving & 41.50 & 3.65 & 9.05 & 28.48 & 23.37 & 21.06 & 1.12 \\
\hline & All & 38.56 & 3.11 & 9.06 & 28.46 & 23.37 & 20.36 & 0.52 \\
\hline & Surviving-All & 2.94 & 0.54 & -0.01 & 0.02 & 0.00 & $\begin{array}{c}0.70 \\
(0.26)\end{array}$ & $\begin{array}{c}0.60 \\
(0.23)\end{array}$ \\
\hline \multirow[t]{3}{*}{ Equity II } & Surviving & 35.60 & 1.66 & 8.75 & 27.32 & 24.78 & 19.46 & -0.97 \\
\hline & All & 34.55 & 1.49 & 9.03 & 27.05 & 24.87 & 19.24 & -0.99 \\
\hline & Surviving-All & 1.05 & 0.17 & -0.28 & 0.28 & -0.10 & $\begin{array}{c}0.22 \\
(0.17)\end{array}$ & $\begin{array}{c}0.02 \\
(0.13)\end{array}$ \\
\hline \multirow[t]{3}{*}{ Bond } & Surviving & 9.30 & -10.33 & 8.29 & 9.59 & 2.01 & 3.72 & -0.57 \\
\hline & All & 8.36 & -9.58 & 8.01 & 9.54 & 2.01 & 3.62 & -0.48 \\
\hline & Surviving-All & 0.94 & -0.75 & 0.28 & 0.05 & 0.00 & $\begin{array}{c}0.10 \\
(0.15)\end{array}$ & $\begin{array}{l}-0.09 \\
(0.10)\end{array}$ \\
\hline \multirow[t]{3}{*}{ Money Market } & Surviving & 0.09 & -1.71 & -0.10 & 1.36 & -0.69 & -0.22 & -0.77 \\
\hline & All & -0.16 & -1.74 & -0.15 & 1.33 & -0.69 & -0.29 & -0.82 \\
\hline & Surviving-All & 0.25 & 0.03 & 0.05 & 0.03 & 0.00 & $\begin{array}{c}0.07 \\
(0.02)\end{array}$ & $\begin{array}{c}0.05 \\
(0.02)\end{array}$ \\
\hline
\end{tabular}

This table shows the average excess returns in \% per year for equally-weighted portfolios of surviving funds, and both surviving and non-surviving (All) funds. The estimates of the survivorship biases for the individual years (1993 to 1997) are measured by the difference between the average portfolio returns for surviving and all funds. For the full period 1993 to 1997, the average difference as well as a conditional alpha measure are reported. The standard errors associated with the average difference and the alpha are given in parentheses. 
Table 4: Cross-Sectional Analysis of Alphas versus Attributes

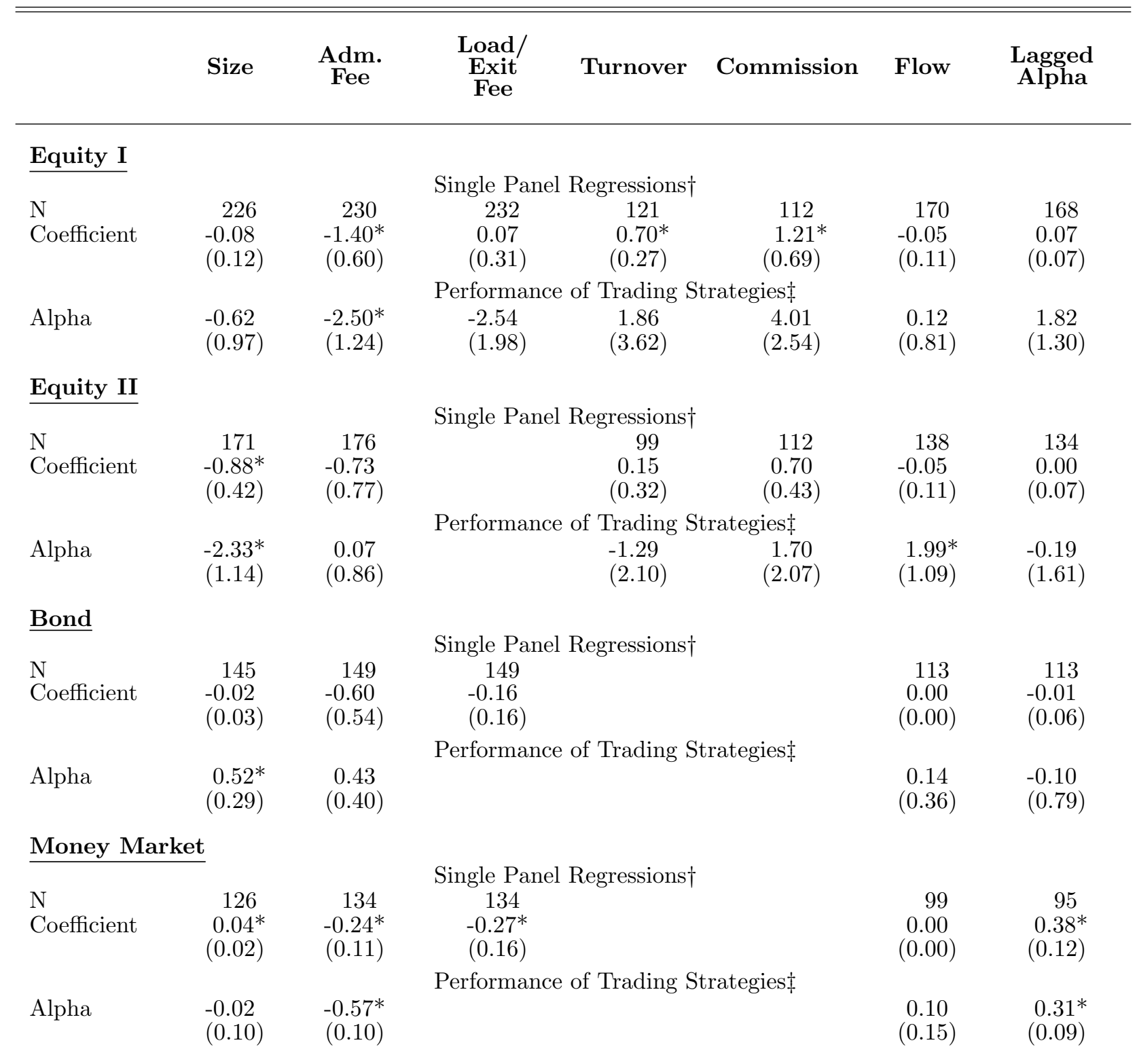

This table relates estimated annual alphas to annual fund attributes. There is, by law, no variation in load/exit fees for Equity II funds. There is too little data on turnover and commission fees for Bond funds and Money Market funds for a meaningful study.

$\dagger$ The single panel regression is a regression of the alpha on a constant and each attribute individually allowing for fixed year effects, see equation (2). The equation is estimated with weighted least squares, where each observation is weighted by the inverse of the standard deviation of the estimated alpha. The slope coefficient is reported. The corresponding heteroskedasticity-consistent standard error is shown in parenthesis below the coefficient. A* refers to a significant coefficient at the $10 \%$ level. $\mathrm{N}$ is the number of observations available.

†The trading strategy is to buy (with equal weights) funds above the 60th percentile of the attribute, and sell (with equal weights) funds below the 40th percentile. The performance of the trading strategy is estimated in the same way as the performance of the funds, and the conditional alpha is reported. The corresponding heteroskedasticity-consistent standard error is shown in parenthesis below the alpha. A * refers to a significant coefficient at the $10 \%$ level. 